\title{
Pengaruh Arus Pengelasan Terhadap Sifat Mekanis Sambungan Butt-Joint Las TIG Aluminium
}

\author{
${ }^{(1) *}$ Wartono, ${ }^{(2)}$ Aprianto \\ ${ }^{(1,2)}$ Program Studi Teknik Mesin, Fakultas Teknologi Industri \\ Institut Teknologi Nasional Yogyakarta \\ ${ }^{(l)}$ e-mail:wartono@itny.ac.id \\ (2)e-mail:aprianto5495@gmail.com \\ Jl. Babarsari, Caturtunggal, Depok, Sleman, Yogyakarta, Telp (0274) 485390 \\ Diterima: 20.05.2021, Disetujui: 29.05.2021, Diterbitkan: 30.05.2021
}

\begin{abstract}
The objective of this research is to find out the effect of welding current on the mechanical properties of the Tungsten Inert Gas (TIG) welding on aluminum. Gas Tungsten Arc Welding (GTAW) or Tungsten Inert Gas (TIG) is a type of electric welding that uses tungsten as an unconsumed electrode. This electrode is used to produce an electric arc. The additional material in the form of a welding rod, which is melted by the arc, fills the seam of the parent material. To prevent oxidation, the noble gas argon is used. The amount of current used is $130 \mathrm{~A}, 140 \mathrm{~A}$, and $150 \mathrm{~A}$. The metal to be welded is aluminum measuring $300 \mathrm{~mm} \times 100 \mathrm{~mm} \times 4 \mathrm{~mm}$, aluminum can be joined using filler metal ER5356. The test results of the chemical composition of the raw material show that it has an Al content of $99.35 \%$. The vickers hardness test shows the highest weld hardness value of $130 \mathrm{~A}$ is 59,43 $\mathrm{kg} / \mathrm{mm}^{2}$, the highest HAZ hardness of $140 \mathrm{~A}$ is $66 \mathrm{~kg} \mathrm{~mm}^{2}$. The tensile test results show that welding with a current of $140 \mathrm{~A}$ has a higher tensile stress value is 98,64 MPa.
\end{abstract}

Keywords: Aluminum, TIG, current variation, mechanical properties.

\begin{abstract}
Abstrak
Penelitian ini bertujuan untuk mengetahui pengaruh arus pengelasan terhadap sifat mekanis sambungan Tungsten Inert Gas (TIG) pada aluminium. Gas Tungsten Arc Welding (GTAW) atau Tungsten Inert Gas (TIG) adalah jenis las listrik yang menggunakan bahan tungsten sebagai elektroda tidak terkonsumsi. Elektroda ini digunakan untuk menghasilkan busur nyala listrik. Bahan penambah berupa batang las (rod), yang dicairkan oleh busur nyala tersebut, mengisi kampuh bahan induk. Untuk mencegah oksidasi digunakan gas mulia argon. Besar arus yang digunakan $130 \mathrm{~A}, 140 \mathrm{~A}$, dan 150 A. Logam yang akan dilas adalah aluminium yang berukuran $300 \mathrm{~mm} \times 100 \mathrm{~mm} \times 4 \mathrm{~mm}$, aluminium disambung dengan menggunakan logam pengisi filler ER5356. Hasil uji komposisi kimia raw material menunjukkan mempunyai unsur kandungan kemurnian Al 99,35\%. Uji kekerasan vickers menunjukkan nilai kekerasan las tertinggi 130 A adalah sebesar $59,43 \mathrm{~kg} / \mathrm{mm}^{2}$, kekerasan $H A Z$ tertinggi $140 \mathrm{~A}$ adalah sebesar $66 \mathrm{~kg} / \mathrm{mm}^{2}$. Hasil pengujian tarik menunjukkan bahwa pengelasan dengan besar arus 140 A memiliki nilai tegangan tarik yang lebih tinggi yaitu 98,64 MPa.
\end{abstract}

Kata kunci : Aluminium, $T I G$, variasi arus, sifat mekanis.

\section{Pendahuluan}

Aluminium dan paduannya merupakan logam yang banyak digunakan dibidang teknik karena mempunyai berbagai keunggulan antara lain ringan, mempunyai sifat mampu bentuk (formability) yang baik, kekuatan tarik, kekuatan tarik relatif cukup, tahan korosi dan sifat mekaniknya dapat ditingkatkan dengan pengerjaan dingin atau perlakuan panas, serta mempunyai sifat mampu las (weldability) yang bervariasi tergantung pada jenis paduannya. Pada paduan aluminium terdapat paduan yang dapat diperlaku-panaskan dan juga paduan yang tidak dapat diperlaku-panaskan. 
Menurut Tata Sunardi, dkk (2000), Aluminium ditemukan pertama kali sebagai suatu unsur pada tahun 1809 oleh Sir Humphrey, dan pertama kali direduksi sebagai logam oleh H. C. Oersted pada tahun 1825. Pada tahun 1886, Paul Heroult di Prancis da C.M. Hall di Amerika secara terpisah telah menemukan logam aluminium dari alumina dengan cara elektrolisasi. Sampai sekarang proses Heroult Hall masih dipakai untuk memproduksi aluminium.

Aluminium adalah logam yang saat ini banyak digunakan untuk bahan konstruksi, karena aluminium mempunyai kelebihan dari pada baja karbon rendah (mild steel), aluminium tersebut ditambah unsur paduan dapat meningkatkan sifat mekanik aluminium tersebut, Aluminium termasuk logam non ferro yang ringan dimana berat jenisnya $2,71 \mathrm{~kg} / \mathrm{m}^{3}$ lebih kecil dari pada baja. Aluminium juga mempunyai ketahanan korosi yang sangat baik, karena mempunyai lapisan oksida yang melindunginya dari oksida lingkungan. Aluminium yang telah dipadukan dengan unsur sifat mekanik yang baik, sehingga logam alumunium paduan banyak digunakan untuk konstruksi (Wiryosumarto, dkk, 2004)

Las merupakan salah satu cara penyambungan yang bersifat permanen dari bagian logam, sehingga jadi satu kesatuan. Definisi American Welding Society (AWS) dan Deutche Industrie Normen (DIN) maka dapat diketahui bahwa, pengelasan adalah proses penyambungan antara bagian logam atau lebih dengan menggunakan panas (Amstead, 1993).

Menurut Sonawan, dkk (2006), pemanasan lokal pada permukaan logam induk selama proses pengelasan menghasilkan daerah pemanasan yang unik, artinya disetiap titik yang mengalami pemanasan itu memiliki karakteristik yang berbeda-beda.

Pengelasan yang sempurna adalah apabila logam pengisi bercampur secara sempurna dengan logam induk. Gagalnya proses pencampuran ini disebabkan oleh adanya lapisan oksida yang menjadi pembatas atau penghalang sehingga mengakibatkan cacat yaitu penetrasi tak sempurna (incomplete penetration). Oleh karena itu dibutuhkan solusi untuk menghilangkan lapisan oksida ini yaitu dengan cara menggunakan proses pengelasan Tungsten Inert Gas (TIG) atau GTAW. Las $T I G$ merupakan jenis las listrik yang menggunakan bahan tungsten sebagai elektroda tidak terkonsumsi. Elektroda ini digunakan hanya untuk menghasilkan busur nyala listrik.

Lapisan oksida ini juga bersifat isolator dimana dapat menghambat mengalirnya arus dalam pengelasan. Jika lapisan oksida cukup tebal maka hal ini dapat menghambat timbulnya busur listrik atau sulit untuk membangkitkan busur listrik. Untuk dapat menjadikan hasil lasan yang baik maka perlu melihat kondisi pengelasan, yang meliputi metode pengelasan, macam-macam arus yang digunakan $(A C, D C$ elektrode positif, $D C$ elektrode negative), arus las, tegangan busur, kecepatan pengelasan, kondisi pemanasan awal, jumlah lajur, jumlah lapisan, suhu antar lajur pengelasan, dan perlakuan panas pasca pengelasan. Kondisi - kondisi pengelasan mengacu pada arus las, tegangan busur dan kecepatan las.

Nopiyana I.W.E., (2015), meneliti tentang pengaruh variasi arus pengelasan terhadap sifat mekanis sambungan las $T I G$ pada aluminium seri 7004. Pengelasan dilakukan dengan variasi arus 80, 90, 100 A pada kampuh V 45 ${ }^{\circ}$. Hasil uji kekerasan Brinell menunjukkan bahwa pada arus 80 A memiliki nilai uji kekerasan yang lebih besar yaitu $59,04 \mathrm{~kg} / \mathrm{mm}^{2}$, dan untuk kekerasan terendah pada arus 90 A yaitu 25,05 $\mathrm{kg} / \mathrm{mm}^{2}$. Hasil pengujian tarik menunjukkan bahwa nilai kekuatan tarik tertinggi pada arus pengelasan 80 A yaitu $93,06 \mathrm{~kg} / \mathrm{mm}^{2}$, dan untuk kekuatan tarik terendah pada arus $90 \mathrm{~A}$ yaitu $63,31 \mathrm{~kg} / \mathrm{mm}^{2}$.

Agustinus Rumangun (2015), meneliti tentang studi pengaruh arus las $T I G$ pada aluminium 5083 terhadap struktur mikro, kekerasan dan kekuatan tarik. Pengelasan dilakukan dengan variasi besar arus 80 A, 90 A, 100 A, dan 110 A. Hasil uji foto mokro terdiri dari struktur senyawa intermetalik $\mathrm{Al}$ (Mg, Mn, Zn) yang lebih mendominan. Uji kekerasan Vickers menunjukkan nilai kekerasan $H A Z$ tertinggi yaitu pada pengelasan dengan besar arus pengelasan $110 \mathrm{~A}$ adalah sebesar $74,2 \mathrm{~kg} / \mathrm{mm}^{2}$. Hasil pengujian tarik menunjukkan bahwa pengelasan dengan arus 110 A memiliki tegangan tarik lebih tinggi yaitu 299,65 MPa. Untuk hasil pengujian terlihat dengan jelas bahwa spesimen dengan besar arus pengelasan yang bervariasi $80 \mathrm{~A}, 90$ A, 100 A dan 110 A dengan posisi pengelasan bawah tangan memiliki tegangan tarik yang 
berbeda-beda, patahan yang terjadi adalah patahan getas. Dari hasil analisis pengelasan $T I G$ dengan variasi besar arus pengelasan dapat disimpulkan bahwa spesimen dengan besar arus pengelasan $110 \mathrm{~A}$ terlihat pada spesimen kualitasnya bagus karena patah di luar daerah las artinya kekuatan lasnya bagus.

M. Utomo Manggala Putra (2016), meneliti tentang pengaruh besar arus pengelasan terhadap sifat fisis dan mekanis sambungan las $T I G$ pada aluminium paduan. Pada umumnya daerah $H A Z$ memiliki kekuatan dan kekerasan lebih rendah dibandingkan daerah weld metal. Dari hasil komposisi kimia menunjukkan bahwa pelat alumunium yang digunakan adalah alumunium seri 4xxx dengan unsur yang lebih dominan adalah Al-Si yang dimana aluminium $97,65 \%$ dan silikon $0,371 \%$. Hasil uji foto mikro terdiri dari struktur $\mathrm{Al}$ dan AL-Si. Uji kekerasan Vickers menunjukkan nilai kekerasan tertinggi pada daerah las yaitu $65,9 \mathrm{~kg} / \mathrm{mm}^{2}$ dan terendah pada daerah $H A Z$ yaitu $57,2 \mathrm{~kg} / \mathrm{mm}^{2}$. Hasil pengujian tarik menunjukkan bahwa pengelasan dengan besar arus $100 \mathrm{~A}$ memiliki nilai kekuatan tarik yang lebih tinggi yaitu $162,55 \mathrm{~kg} / \mathrm{mm}^{2}$, sedangkan kekuatan tarik terendah pada arus 110 A yaitu $83,14 \mathrm{~kg} / \mathrm{mm}^{2}$. Dari hasil analisis pengelasan $T I G$ dengan variasi besar arus pengelasan dapat ditarik kesimpulan bahwa daerah terjadinya patah didominasi pada sambungan weld metal, hal ini bisa terjadi karena disebabkan oleh perbedaan kecepatan pendinginan karena panas pengelasan, filler pengelasan yang tidak sesuai material las, atau ketebalan plat sehingga bisa mnyebabkan terjadinya porositas pada spesimen uji.

Munawir Jalal (2017), meneliti tentang pengaruh suhu preheat terhadap sifat mekanis dan struktur mikro sambungan $T I G$ pada aluminium paduan. Hasil pengujian tarik menunjukkan bahwa patah tarik terjadi di daerah batas antara $H A Z$ kasar dan $H A Z$ halus. Hal ini disebabkan daerah batas ini mempunyai kekuatan dan kekerasan yang paling rendah, sehingga merupakan daerah yang paling lemah.

\section{Bahan dan Metode}

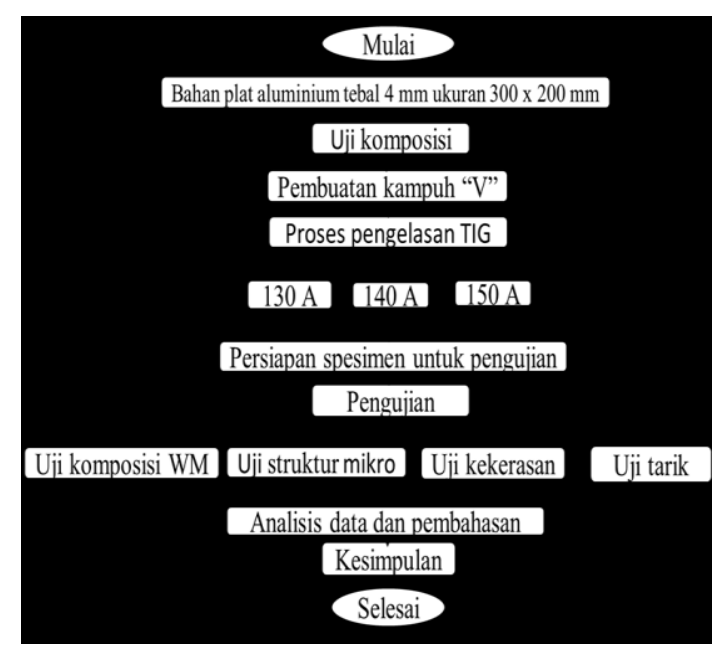

Gambar 1. Diagram alir

\section{A. Bahan Penelitian}

Bahan-bahan yang digunakan :

1. Plat aluminium berukuran $600 \times 800 \times 4$ $\mathrm{mm}$

2. Elektroda Pure Tungsten

3. Kawat las ER5356 diameter 2,4 mm

4. Bahan pendukung lain berupa :
a. Resin
b. Katalis
c. Waslap
d. Doble tip
e. Amplas tahan air ukuran : 180, 240, 400, $600,800,1000,1500,2000$ mesh.
f. Kain bludru.

Bahan plat aluminium yang disediakan berukuran $600 \mathrm{~mm}$ x $800 \mathrm{~mm} \times 4 \mathrm{~mm}$, kemudian dipotong dan difrais hingga rata dan siku, dengan ukuran $300 \times 100$ x $4 \mathrm{~mm}$ sebanyak 16 buah. Setelah didapatkan ukuran yang diinginkan kemudian dilanjutkan dengan pembuatan kampuh $\mathrm{V}$.

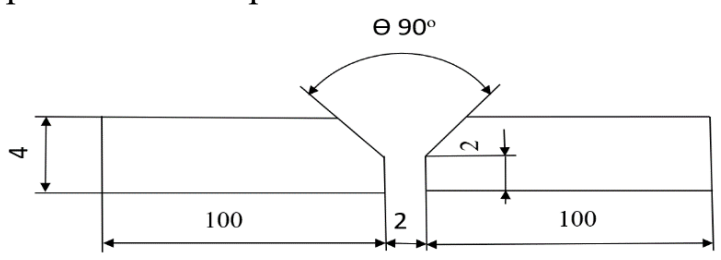

Gambar 2. Pembuatan kampuh

Sebelum dilakukan proses pengujian tarik, kekerasan dan struktur mikro terlebih dahulu spesimen dipersiapkan melalui tahap-tahap sebagai berikut:

1. Pemotongan dari lembaran hasil pengelasan dengan variasi besar arus kemudian 
dipotong lagi menjadi potongan-potongan kecil, sesuai dengan proses pengujian yang akan dilakukan.

Pengujian struktur mikro dan pengujian kekerasan dengan ukuran ( $\mathrm{mm})$

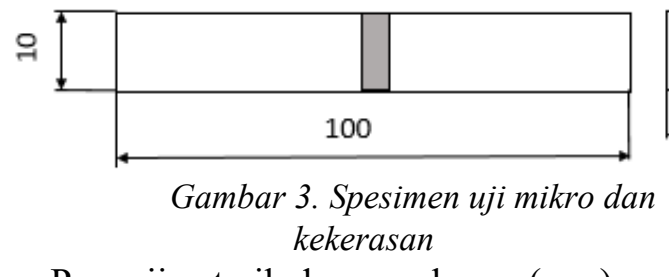

Pengujian tarik dengan ukuran (mm)

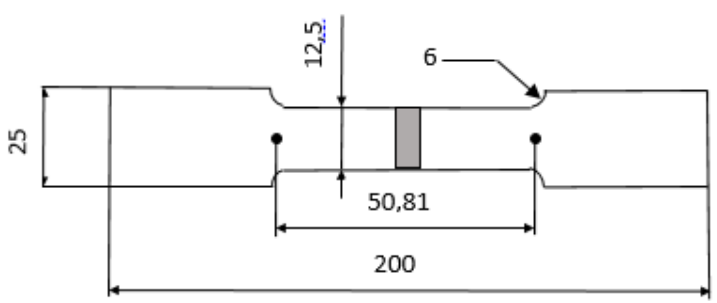

Gambar 4. Spesimen uji tarik

\section{Pengamplasan}

Proses pengamplasan dilakukan untuk menghilangkan bagian yang kasar akibat dari pemotongan benda uji. Dalam proses pengamplasan amplas yang digunakan dimulai dari grid yang kasar sampai halus, dari nomor yang paling kecil sampai nomor yang paling besar. Pada penelitian ini amplas yang digunakan jenis amplas tahan air yang terdiri dari nomor amplas 180, 240, 400, 600, 800, 1000, 1500, dan 2000 mesh. Pengamplasan dilakukan dengan mesin kertas amplas diklem diatas mesin yang berputar kemudian benda uji digesekkan pada amplas yang diputar oleh mesin dengan tangan sampai didapatkan permukaan rata dan mengkilap. Selama proses pengamplasan juga dilakukan pendingin dengan menuangkan air terus menerus pada bidang gesekan untuk menghindari terjadinya panas pada permukaan benda uji dan untuk mendapatkan permukaan yang halus.

3. Memoles

Pemolesan dilakukan pada benda uji yang akan dilihat struktur mikronya dan pengujian kekerasan, karena syaratnya yang harus dipenuhi permukaan benda uji adalah rata dan bebas kotoran. Sebagai bahan pemoles digunakan autosol yang berfungsi sebagai pengkilatan permukaan yang kasar dan menghilangkan bekas pemakanan serta goresan akibat proses pengamplasan. Pemolesan dilakukan dengan memberikan autosol pada permukaan uji dengan menggosokkan pada kain yang halus hingga rata, pemolesan dilakukan hingga mendapatkan permukaan benda uji yang mengkilap. Setelah itu spesimen dietsa dengan larutan HNO3 kemudian dilakukan pencucian dengan aquades agar dapat diketahui struktur mikro dari aluminium tersebut.

\section{Hasil dan Pembahasan}

\section{Pengujian komposisi kimia}

Dari hasil pengujian komposisi kimia pada spesimen uji aluminium paduan, didapatkan hasil sebagai berikut :

Tabel 1. Hasil pengujian komposisi kimia

\begin{tabular}{|c|c|c|c|c|}
\hline \multirow{2}{*}{ UNSUR } & \multicolumn{4}{|c|}{ SAMPEL UJI } \\
\cline { 2 - 5 } & $\begin{array}{c}\text { Raw } \\
\text { metal }\end{array}$ & $\mathrm{I}=130 \mathrm{~A}$ & $\mathrm{I}=140 \mathrm{~A}$ & $\mathrm{I}=150 \mathrm{~A}$ \\
\hline $\mathrm{Al}$ & 99,35 & 89,67 & 95,63 & 95,18 \\
\hline $\mathrm{Si}$ & $<0,0500$ & 2,192 & 1,014 & 1,039 \\
\hline $\mathrm{Fe}$ & $<0,0500$ & 0,753 & 0,101 & 0,083 \\
\hline $\mathrm{Cu}$ & 0,153 & 0,244 & 0,099 & 0,086 \\
\hline $\mathrm{Mn}$ & 0,0310 & 0,165 & 0,138 & 0,138 \\
\hline $\mathrm{Mg}$ & $<0,0500$ & 4,935 & 2,714 & 3,168 \\
\hline $\mathrm{Cr}$ & 0,0654 & 0,143 & 0,036 & 0,039 \\
\hline $\mathrm{Ni}$ & $<0,0200$ & 0,126 & $<0,0050$ & $<0,0050$ \\
\hline $\mathrm{Zn}$ & 0,104 & 0,227 & 0,050 & 0,050 \\
\hline $\mathrm{Sn}$ & $<0,0500$ & 0,220 & $<0,0050$ & $<0,0050$ \\
\hline $\mathrm{Ti}$ & $<0,0100$ & 0,129 & 0,073 & 0,073 \\
\hline $\mathrm{Pb}$ & $<0,0300$ & 0,230 & $<0,0050$ & $<0,0050$ \\
\hline $\mathrm{Be}$ & 0,001 & - & - & - \\
\hline $\mathrm{Ca}$ & 0,0035 & 0,048 & $<0,0010$ & $<0,0010$ \\
\hline $\mathrm{Sr}$ & $<0,005$ & 0,040 & $<0,0020$ & $<0,0020$ \\
\hline $\mathrm{Li}$ & - & 0,604 & $<0,300$ & $<0,300$ \\
\hline $\mathrm{Bi}$ & - & 0,063 & $<0,0060$ & $<0,0060$ \\
\hline $\mathrm{Ag}$ & - & 0,0083 & $<0,0010$ & $<0,0010$ \\
\hline $\mathrm{B}$ & - & 0,054 & $<0,0010$ & $<0,0010$ \\
\hline $\mathrm{V}$ & $<0,0100$ & 0,036 & 0,014 & 0,014 \\
\hline
\end{tabular}

Uji komposisi ini dilakukan pada 2 posisi tembak yaitu pada raw material dan daerah las (weld metal), pengujian dilakukan untuk mengetahui berapa presentase unsur yang terkandung dalam plat aluminium paduan yang belum terpengaruh pengelasan (raw material) maupun yang telah terpengaruh oleh pengelasan sehingga dapat diketahui perbandingan kadar kandungan unsur kimia dari kedua benda uji tersebut. 
Tabel 1, menunjukkan bahwa raw material mengandung unsur utama : Al sebesar 99,35\%, $\mathrm{Cu}$ sebesar $0,153 \%, \mathrm{Zn}$ sebesar $0,104 \%$, Cr sebesar $0,0654 \%$. Semula diduga bahwa raw material adalah paduan aluminium seri $7 \mathrm{xxx}$, tetapi setelah dicari kecocokan ternyata aluminium yang digunakan adalah seri 1xxx karena pada seri 7xxx Zinc (1\% - 8,2\%), sementara aluminium yang digunakan dibawah $1 \%$.

Sedangkan pada daerah las (weld metal) terdapat kandungan unsur $\mathrm{Mg}, \mathrm{Si}, \mathrm{Fe}, \mathrm{Li}$. Pada setiap arus yang digunakan memiliki nilai yang berbeda seperti pada Tabel 1 akan tetapi tetap unsur tersebutlah yang paling unggul. Pada daerah las kandungan $\mathrm{Mg}$ terlihat lebih besar dari pada raw material dikarenakan pada daerah las ada penambahan filler ER 5356 dimana kandungan filler tersebut mempunyai unsur $\mathrm{Mg} \mathrm{4,5 \%} \mathrm{-} \mathrm{5,5 \% .}$

\section{Pengujian kekerasan vickers.}

Menurut Schonmetz, A., dkk. (1977), pengujian kekerasan mikro vickers, harga ditunjukkan oleh penetrator yang terbuat dari piramida intan, sudut antara dua bidang sisi piramida $136^{\circ}$. Identor ditekankan ke permukaan bagian yang akan diukur dengan beban 200 gr. Besarnya diagonal bekas injakan diukur dengan mikroskop dan nilai kekerasan Vickers dapat dihitung dengan rumus sebagai berikut :

$$
\mathrm{VHN}=1,854 \times \mathrm{F} / \mathrm{D}^{2}\left(\mathrm{~kg} / \mathrm{mm}^{2}\right)
$$

Dimana : $\mathrm{F}=$ Benda yang diterapkan $(\mathrm{kg})$

$\mathrm{D}=$ Panjang diagonal rata-rata $(\mathrm{mm})$

$\mathrm{D}=\left(\mathrm{d}_{1}+\mathrm{d}_{2}\right) / 2$

$\mathrm{d}_{1}=$ Panjang diagonal satu

$\mathrm{d}_{2}=$ Panjang diagonal dua

Pengujian kekerasan untuk mengetahui distribusi kekerasan didaerah logam induk, logam $H A Z$ dan logam las dari hasil proses las $T I G$ dilakukan dengan metode pengujian Vickers. Angka kekerasan Vickers (angka kekerasan piramida intan) didefinisikan sebagai beban dibagi luas permukaan bekas penekanan. Pada prakteknya, bekas penekanan diukur dengan mikroskop pada panjang diagonalnya, gambar diagram 6,7 , dan 8 .

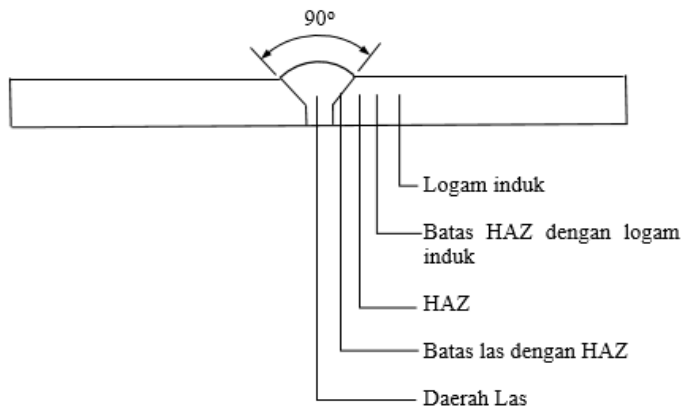

Gambar 5. Titik Uji kekerasan

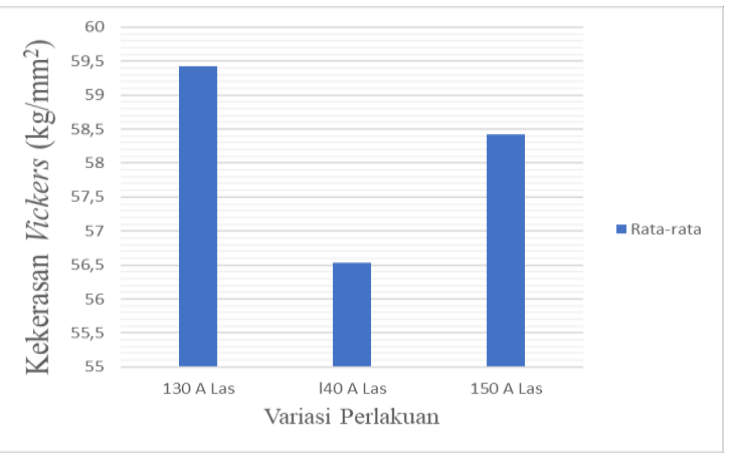

Gambar 6. Diagram kekerasan vickers daerah las (weld metal)

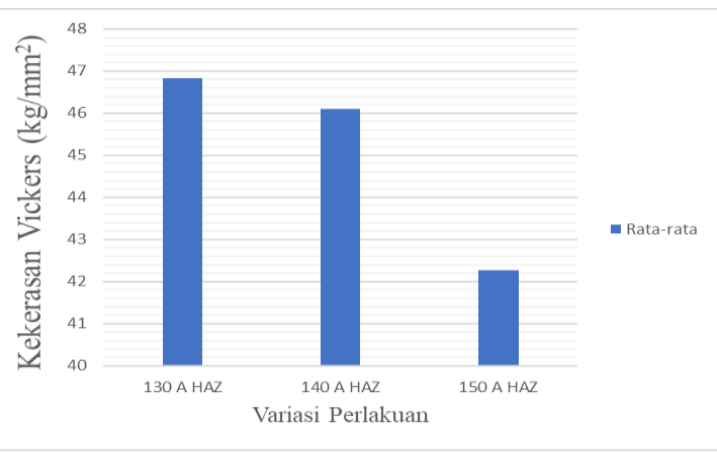

Gambar 7. Diagram kekerasan vickers daerah $H A Z$

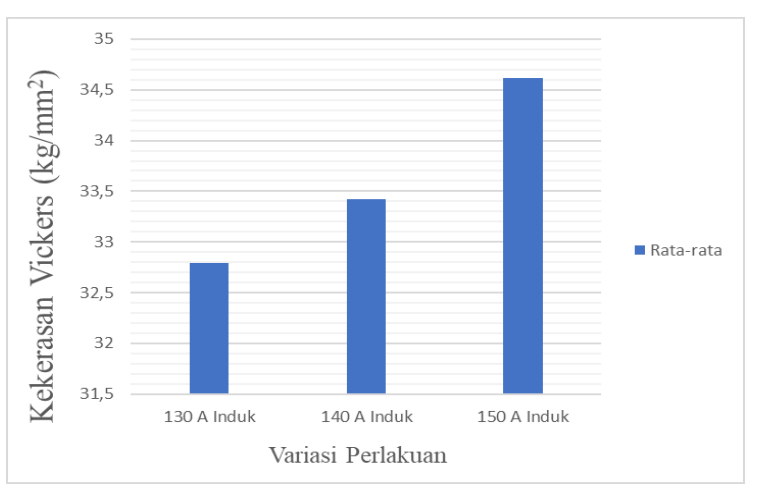

Gambar 8. Diagram kekerasan vickers daerah logam induk 


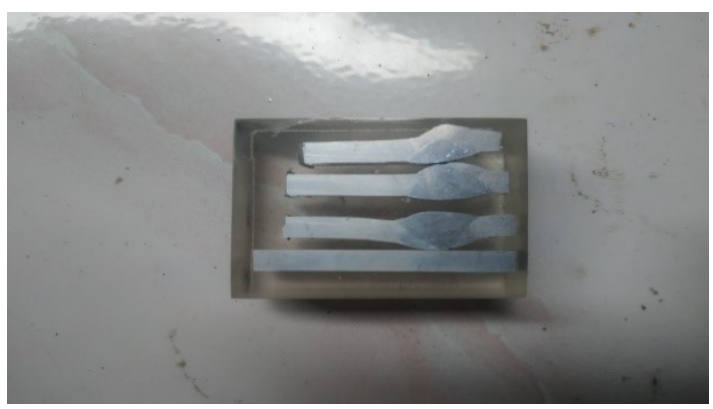

Gambar 9. Spesimen uji kekerasan

Dari hasil pengujian terlihat harga kekerasan pada setiap titik mengalami kenaikan. Proses pengelasan aluminium menyebabkan daerah yang menerima panas lebih besar melampaui suhu kritis dari aluminium yaitu pada $H A Z$ dan weld metal. Oleh karena itu nilai kekerasan pada $H A Z$ cenderung naik. Selain itu naiknya kekerasan dipengaruhi adanya unsur $\mathrm{Mg}$, pada daerah weld metal harga distribusi kekerasan paling tinggi, hal ini dipengaruhi oleh banyaknya kandungan $\mathrm{Al}(\mathrm{Mg}, \mathrm{Si})$ akibat penggunaan filler ER 5356. Jadi dapat dikatakan bahwa pada daerah weld metal nilai distribusi kekerasan lebih meningkat dari daerah $H A Z$, walaupun nilai ditribusi kekerasan daerah $H A Z$ cenderung naik kemudian mengalami penurunan. Untuk keseluruhan arus yang baik dari hasil data arus 130 A, 140 A, 150 A adalah 130 A karena memiliki harga kekerasan tertinggi pada weld metal yaitu sebesar 59,43 $\mathrm{kg} / \mathrm{mm}^{2}$ dibandingkan pada daerah $H A Z$ dan logam induk.

\section{Pengujian tarik}

Aluminium paduan setelah dilakukan proses pengelasan $T I G$ mempunyai ukuran panjang $300 \mathrm{~mm} \quad$ x $200 \mathrm{~mm}$ x $4 \mathrm{~mm}$. Selanjutnya dibuat spesimen uji tarik sesuai besar arus pengelasan, masing-masing sebanyak 3 buah. Hasil uji tarik seperti ditunjukkan pada tabel 3 dan 4 hasil pengujian ditunjukan pada gambar 10 dan gambar 11 .
Tabel 3. Hasil uji tarik tegangan pada arus $130 \mathrm{~A}$, $140 \mathrm{~A}, 150 \mathrm{~A}$

\begin{tabular}{|c|c|c|c|c|c|c|}
\hline No & $\begin{array}{c}\text { Variasi } \\
\text { perlakuan }\end{array}$ & $\begin{array}{c}\text { Tabel } \\
(\mathrm{mm})\end{array}$ & $\begin{array}{c}\text { Lebar } \\
(\mathrm{mm})\end{array}$ & $\begin{array}{c}\text { Pmax } \\
(\mathrm{KN})\end{array}$ & $\begin{array}{c}\Delta \mathrm{L} \\
(\mathrm{mm})\end{array}$ & $\begin{array}{c}\text { Tegangan tarik } \\
(\mathrm{MPa})\end{array}$ \\
\hline 1 & Arus 1301 & 4,24 & 12,73 & 4,93 & 7,15 & 91,338 \\
\hline 2 & Arus 1302 & 4,16 & 12,87 & 5,14 & 8,94 & 96,004 \\
\hline 3 & Arus $130 \quad 3$ & 4,14 & 12,85 & 5,16 & 9,01 & 96,994 \\
\hline 4 & Arus 1401 & 4,08 & 12,71 & 4,90 & 7,37 & 94,490 \\
\hline 5 & Arus 140 2 & 4,06 & 12,51 & 5,01 & 9,68 & 98,640 \\
\hline 6 & Arus 140 3 & 4,12 & 12,69 & 5,14 & 8,75 & 98,311 \\
\hline 7 & Arus 150 1 & 4,12 & 12,69 & 5,09 & 6,03 & 97,355 \\
\hline 8 & Arus 150 2 & 4,08 & 12,52 & 5,00 & 9,67 & 97,882 \\
\hline 9 & Arus 150 3 & 4,09 & 12,40 & 4,93 & 9,06 & 97,207 \\
\hline
\end{tabular}

Tabel 4. Hasil uji tarik regangan pada arus $130 \mathrm{~A}$, $140 \mathrm{~A}, 150 \mathrm{~A}$

\begin{tabular}{|c|c|c|c|c|c|c|}
\hline No & $\begin{array}{c}\text { Variasi } \\
\text { perlakuan }\end{array}$ & $\begin{array}{c}\text { Tabel } \\
(\mathrm{mm})\end{array}$ & $\begin{array}{c}\text { Lebar } \\
(\mathrm{mm})\end{array}$ & $\begin{array}{c}\text { Pmax } \\
(\mathrm{KN})\end{array}$ & $\begin{array}{c}\Delta \mathrm{L} \\
(\mathrm{mm})\end{array}$ & $\begin{array}{c}\text { Regangan } \\
(\%)\end{array}$ \\
\hline 1 & Arus 130 1 & 4,24 & 12,73 & 4,93 & 7,15 & 0,15 \\
\hline 2 & Arus 1302 & 4,16 & 12,87 & 5,14 & 8,94 & 0,19 \\
\hline 3 & Arus 130 3 & 4,14 & 12,85 & 5,16 & 9,01 & 0,20 \\
\hline 4 & Arus 140 1 & 4,08 & 12,71 & 4,90 & 7,37 & 0,16 \\
\hline 5 & Arus 140 2 & 4,06 & 12,51 & 5,01 & 9,68 & 0,21 \\
\hline 6 & Arus 140 3 & 4,12 & 12,69 & 5,14 & 8,75 & 0,19 \\
\hline 7 & Arus 150_1 & 4,12 & 12,69 & 5,09 & 6,03 & 0,13 \\
\hline 8 & Arus 150 2 & 4,08 & 12,52 & 5,00 & 9,67 & 0,21 \\
\hline 9 & Arus 150 3 & 4,09 & 12,40 & 4,93 & 9,06 & 0,20 \\
\hline
\end{tabular}

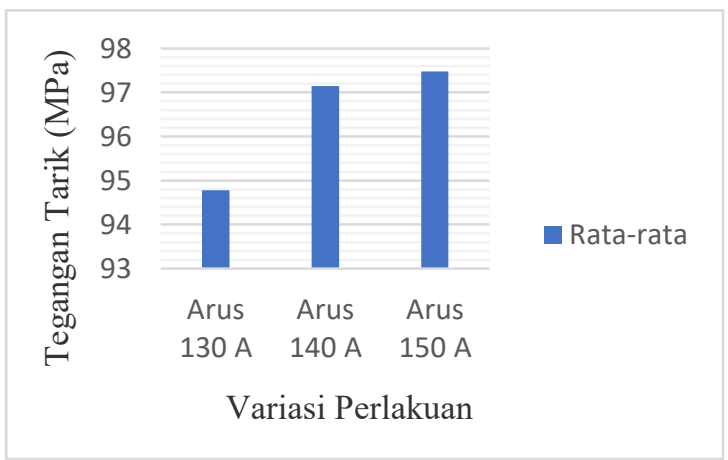

Gambar 10. Diagram Tegangan Tarik 


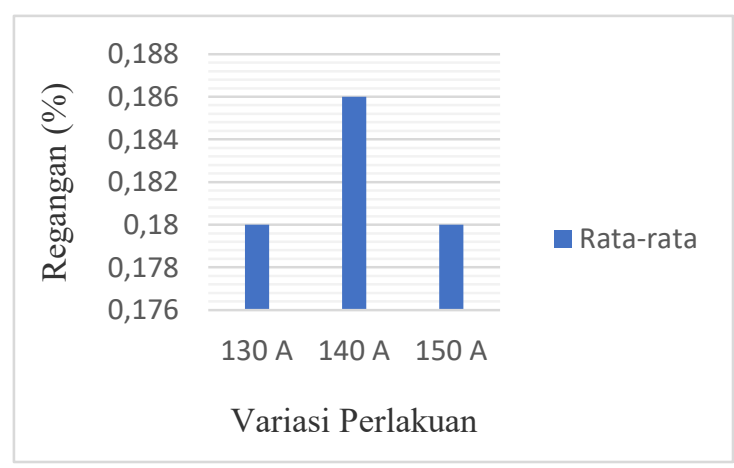

Gambar 11. Diagram Regangan

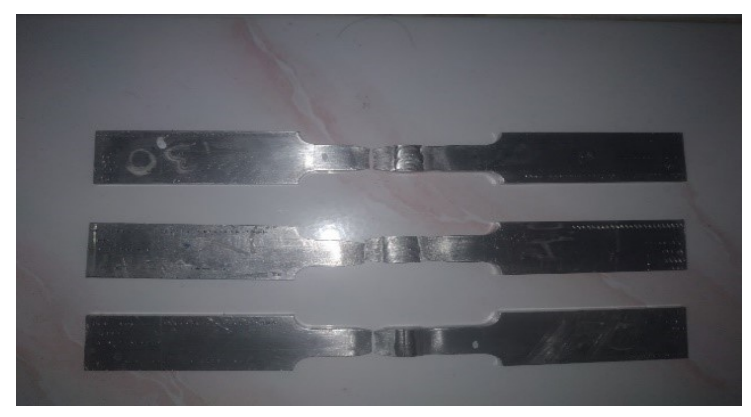

Gambar 12. Spesimen uji tarik 130 A setelah putus

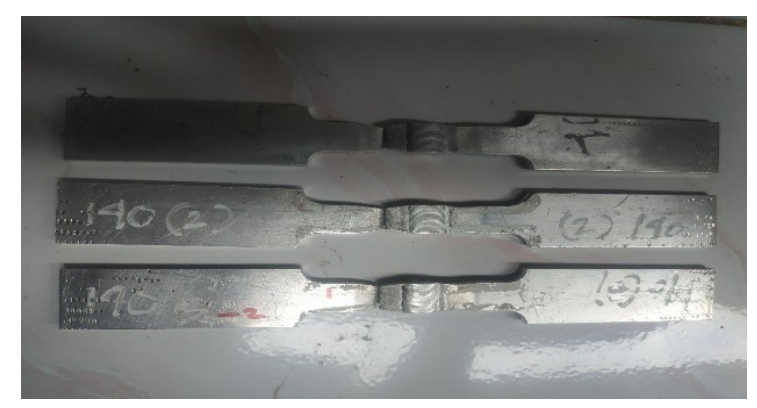

Gambar 13. Spesimen uji tarik 140 A setelah putus

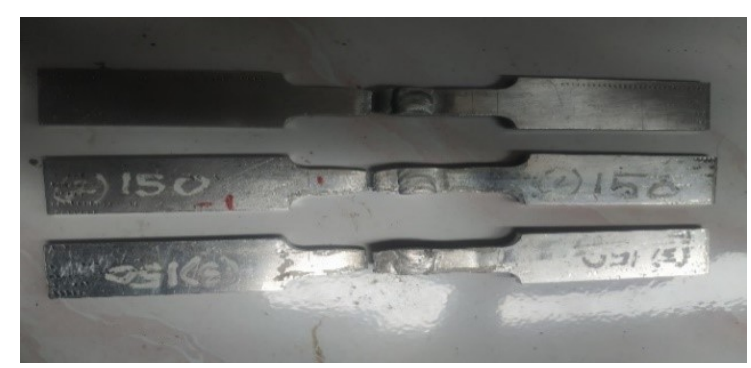

Gambar 14. Spesimen uji tarik 150 A setelah putus

Kekuatan tarik suatu material dapat dipengaruhi oleh banyak hal, selain karena komposisi kimia dan proses pembuatannya, kekuatan tarik juga dapat dipengaruhi oleh perlakuan-perlakuan tertentu yang dapat menyebabkan perubahan nilai kekuatan tarik tersebut. Pada penelitian ini perlakuan tersebut dimaksudkan pada pengaruh banyaknya proses repair welding pada pengelasan Tungsten Inert Gas (TIG). Seperti diketahui bahwa proses pemanasan dan pendinginan dapat menyebabkan adanya tengangan sisa dalam suatu bahan material, dan tegangan sisa itu sendiri dapat menurunkan sifat mekanik dari suatu material terutama kekuatan tarik dan kekerasannya. Pada spesimen dengan besar arus yang bervariasi terlihat dari pengujian tarik bahwa, pengujian tarik dengan besar arus 130 A,140 A dan 150 A memiliki kekuatan tarik yang berbeda.

Dari hasil pengujian tarik dapat terlihat bahwa spesimen mengalami patah pada daerah $H A Z$, hal ini disebabkan karena daerah $H A Z$ adalah daerah paling kritis dari sambungan las, karena selain berubah strukturnya juga terjadi perubahan sifat pada daerah ini. Namun jika kita melihat dari hasil perhitungannya, dapat terlihat jelas perbedaannya pada setiap arus, dimana arus 150 A hasilnya sedikit lebih tinggi bila dibandingkan yang lain. Jadi dikatakan semakin besar arus pengelasannya semakin meningkat nilai kekuatan tariknya.

\section{Kesimpulan}

Dari hasil penelitian diatas dapat disimpulkan sebagai berikut:

1. Hasil uji komposisi kimia pada raw material menunjukkan bahwa plat aluminium yang digunakan merupakan aluminium seri 1 xxx dengan kemurnian $\mathrm{Al}$ $(99,35 \%)$. Namun pada saat pengujian komposisi kimia pada weld metal terjadi perubahan unsur yaitu pada arus $130 \mathrm{~A}$, unsur Al (89,67\%), $\mathrm{Mg}$ (4,935\%), Si $(2,192 \%)$, dan $\mathrm{Fe}(0,753 \%)$, penyebab perubahan tersebut dikarenakan pada daerah las ada pengaruh penggunaan filler ER 5356 dimana kandungan filler tersebut mempunyai unsur $\mathrm{Mg}$ 4,5\% - 5,5\%.

2. Hasil uji kekerasan Vickers menunjukkan bahwa nilai kekerasan pengelasan pada arus 130 A yaitu sebesar $59,43 \mathrm{~kg} / \mathrm{mm}^{2}$, memiliki nilai kekerasan yang lebih tinggi dibandingkan pengelasan pada arus $140 \mathrm{~A}$ dan $150 \mathrm{~A}$.

3. Hasil pengujian tarik menunjukkan bahwa pengelasan dengan besar arus 140 A hasil kekuatan tariknya yaitu sebesar 98,64 MPa, mempunyai nilai kekuatan tarik yang lebih 
tinggi dibandingkan dengan pengelasan pada arus $130 \mathrm{~A}$ dan $150 \mathrm{~A}$

\section{Ucapan Terima Kasih}

Terimakasih kepada semua pihak yang telah membantu dalam penelitian ini, terutama laboratorium material teknik ITNY dan laboratorium material Teknik Mesin D3 UGM Yogyakarta.

\section{Daftar Pustaka}

Amstead, B.H., Ostwald, P.F., dan Begeman, M.L., 1993, “Teknologi Mekanik”, Jilid 1, Edisi Ketujuh, terj. Djaprie S., Erlangga, Jakarta.

Agustinus, R. , 2015, "Studi Pengaruh Arus Las TIG pada Aluminium 5083 Terhadap Struktur Mikro, Kekerasan dan Kekuatan Tarik", Teknik Mesin ITNY, Yogyakarta.

M. Utomo, M. P, 2016, "Pengaruh Besar Arus Pengelasan Terhadap Sifat Fisis dan Mekanis Sambungan Las TIG pada Aluminium Paduan", Teknik Mesin ITNY, Yogyakarta.

Munawir Jalal, 2017, "Pengaruh Suhu Preheat Terhadap Sifat Mekanis dan Struktur Mikro Sambungan TIG Pada Aluminium Paduan”, Teknik Mesin ITNY, Yogyakarta.

Nopiyana I.W.E., 2015, "Pengaruh Variasi Arus Pengelasan Terhadap Sifat Mekanis Sambungan Las TIG pada Aluminium Seri 7004", Teknik Mesin ITNY, Yogyakarya.

Schonmetz, A., Gruber, K. 1977, "Pengetahuan Bahan Dalam Pengerjaan Logam", Bandung: PT. Angkasa, Bandung.

Sonawan W. dan Suratman R. 2006, "Pengantar Untuk Memahami Proses Pengelasan Logam" PT. Alfabeta, Bandung.

Tata Sunardi dan Shinroku Saito, 2000, "Pengetahuan Bahan Teknik", Penerbit PT. Pradnya Paramita, Jakarta.

Wiryosumarto, H. dan Okumura,. T. 2004, "Teknologi Pengelasan Logam", Penerbit PT. Pradnya Paramita, Jakarta. 